Tarbawi: Jurnal Ilmu Pendidikan p-ISSN:1858-1080 | e-ISSN: 2615-6547

Vol. 16, No. 2, Desember 2020, 110 - 119

\title{
Pembelajaran Kooperatif dengan Metode Personal Selling Presentation dan Café World: Model Pembelajaran untuk Meningkatkan Kemampuan Kognitif Memahami
}

\author{
Indah Pujiastuti \\ Universitas Maritim Raja Ali Haji \\ E-mail: indah.puji@umrah.ac.id
}

\begin{abstract}
Abstrak. Ranah kognitif “memahami” adalah tingkat kemampuan kognitif yang penting sebelum berlanjut ke jenjang koginitif yang lebih tinggi. Berdasarkan hal tersebut, penelitian ini merupakan penelitian untuk melihat proses kognitif "memahami" mahasiswa menggunakan dua model pembelajaran. Dua model pembelajaran yang dimaksud adalah model Pembelajaran Kooperatif dengan metode Personal Selling Presentation dan model pembelajaran World Cafe. Penelitian ini adalah penelitian quasi eksperimen dengan rancangan post test only control group design. Populasi penelitian ini adalah seluruh mahasiswa Prodi Pendidikan Bahasa dan Sastra Indonesia yang mengikuti mata kuliah Telaah Kurikulum dan Buku Teks, sampel yang diambil adalah keseluruhan populasi/sampel jenuh. Sampel dibagi 3 kelompok yaitu kelas I-01 sebagai kelompok eksperimen 1, kelas I-02 sebagai kelompok eksperimen 2, dan kelas I-03 sebagai kelompok kontrol. Data didapatkan melalui tes bebentuk uraian. Hasil penelitian didapatkan melalui uji hipotesis menggunakan uji anava satu jalur. Hasil menunjukkan bahwa terdapat perbedaan hasil proses kognitif "memahami" antara ketiga kelompok. Untuk melihat perbedaan lebih jauh, hasil post hoc menunjukkan bahwa kelompok eksperimen 1 dan 2 tidak memiliki perbedaan kemampuan "memahami" secara signifikan. Namun, kelompok eksperimen 1 dan 2 memiliki perbedaan yang siginifikan dengan kelompok control. Simpulannya model Pembelajaran Kooperatif dengan metode Personal Selling Presentation dan model Pembelajaran World Cafe dapat meningkatkan hasil belajar pada ranah kognitif "memahami". Jadi, pendidik dapat memanfatkan dua model pembelajaran ini untuk kegiatan belajar yang bersifat teori atau topik pembelajaran.yang memiliki karakteristik serupa.
\end{abstract}

Kata kunci: Dimensi Kognitif Memahami, Metode Personal Selling Presentation, Model World Café, Pembelajaran Kooperatif

\begin{abstract}
Cognitive domain "understand" is an important ability before continuing to the next level. Based on these, this research aims see the understanding ability of students using two learning models. They were a cooperative learning with "personal selling" techniques and world café. This research is a quasi experimental by using post test only control group design. The population is all students in the department of Indonesian language and literature, umrah who took telaah kurikulum dan buku teks course. Sample taken using saturation sampling. The samples of this research were the students of $i-01, i-02$, and $i-03$. The data was collected by using essay test. The techniques of analyzing data is one way anova test. The result means that there is difference the three groups. To see further differences then use post hoc. The results show the experimental groups 1 and 2 have no significant differences. However, the experimental groups 1 and 2 have significant differences with the control group. Hence, it can be concluded that the cooperative learning with "personal selling" techniques and world café models can improve learning outcomes at the domain cognitive understand. Teacher or lecturers can take advantage of these two learning models for learning acitivities that are theoretical or learning topics that have in common.
\end{abstract}

Key Words: Cooperative Learning, Personal Selling Presentation, World Café Model, Cognitive Understanding Domain 


\section{PENDAHULUAN}

Dalam dunia pendidikan, ada hal yang berlaku bahwa pembelajaran diawali dari hal yang mudah ke yang sukar, yang konkret ke yang abstrak, seperti dalam tingkatan ranah kognitif Anderson, dari level 1 hingga level 6 (C1-C6). Tingkatan level tersebut adalah mengingat, memahami, mengaplikasikan, menganalisis, mengevaluasi, dan membuat (Anderson \& Krathwohl, 2010). Seorang siswa akan memproses pengetahuan yang diterima sesuai dengan proses kognitif.

Mata kuliah Telaah dan Kurikulum Buku Teks adalah mata kuliah pada jenjang perkuliahan S1, Program Studi Pendidikan Bahasa dan Sastra Indonesia di Fakultas Keguruan dan Ilmu Pendidikan, Universitas Maritim Raja Ali Haji. Mata kuliah ini diisi dengan pembahasan tentang keseluruhan dari bagian-bagian yang membangun sebuah kurikulum dan buku teks. Tujuan akhir dari mata kuliah ini adalah mahasiswa dapat melakukan penilaian (mengevaluasi) kurikulum dan buku teks. Tingkatan kognitif pada tujuan akhir adalah "mengevaluasi" (C-4). Jika mahasiswa tidak mampu memahami teori dan konsep kurikulum tersebut, mereka akan kesulitan untuk mencapai kompetensi selanjutnya. Jacobsen, Eggen, \& Kauchak (2009) menyatakan bahwa perkembangan kognitif seseorang bersifat hierarki sehingga untuk keberhasilan setiap tingkatan kognitif dipengaruhi oleh tingkatan/level yang lebih rendah.

Tujuan utama dari perkuliahan ini adalah menumbuhkan kemampuan transfer. Fokusnya adalah proses kognitif "memamahami" sampai "mencipta". Hal yang mendasari adalah proses "memahami". Ini sesuai dengan pernyataan yang disampaikan Anderson \& Krathwohl (2010) bahwa "Proses kognitif yang berpijak pada kemampuan transfer dan ditekankan di sekolah-sekolah dan perguruan tinggi ialah Memahami".

Akan tetapi, dalam implementasinya, masih sulit untuk menumbuhkan kemampuan proses kognitf C2-C6. Hal ini dibuktikan dari hasil evaluasi mata kuliah Telaah Kurikulum dan Buku Teks tahun akademik sebelumnya yang belum optimal. Rata-rata nilai Ujian Tengah Semester (UTS) adalah 60.86 dan Ujian Akhir Sekolah (UAS) adalah 54.52. Dalam konteks ini, Mahasiswa dapat dengan mudah menjawab pertanyaan-pertanyaan ingatan, seperti "Jelaskan dua contoh prinsip kurikulum!". Namun, mahasiswa mulai kesulitan dalam menjawab pertanyaan berikut "Berikan contoh pelaksanaan prinsip kurikulum di sekolah!", padahal pertanyaan ini merupakan pertanyaan untuk kemampuan memahami. Akibatnya, ketika mahasiswa diberikan tugas untuk menganalisis kompetensi dasar kurikulum, mahasiswa tidak mampu mengerjakannya dengan baik.

Hal ini sebenarnya sudah terlihat dalam proses belajar mengajar terutama dalam berdiskusi. Tanya jawab yang dilakukan oleh mahasiswa, pertanyaan-pertanyaan yang dilontarkan hanya berkisar pada pertanyaan ingatan, yang sebenarnya jawabannya bisa ditemukan di buku bahkan mencari di google. Mahasiswa yang menyajikan materi pun, hanya terpusat pada buku dan copy-paste isi buku ke slide power point.

Fenomena ini ternyata juga terjadi pada penelitian Muhson (2009) yang berjudul "Peningkatan Minat Belajar dan Pemahaman Mahasiswa Melalui Penerapan Problem Based Learning", bahwa permasalahan dalam penelitian tersebut mahasiswa hanya mampu menjawab soal yang sifatnya teoretis. Ketika mahasiswa diberikan pertanyaan untuk tingkatan kognitif yang lebih tinggi, sebagian besar mahasiswa tidak dapat menjawab dengan benar. Penelitian Hadi (2016), juga menjelaskan tentang kesulitan-kesulitan dalam Mata Kuliah Telaah Kurikulum dan Buku Teks, yang disebabkan karena pemahaman konsep dan prinsip yang kurang. Mahasiswa sebenarnya masih memiliki ketergantungan pada bahan ajar, buku, dan google.

Untuk mencoba mengatasi masalah tersebut, penelitian ini mencoba dua model pembelajaran dalam perkuliahan. "Pembelajaran kooperatif" dan "world cafe" yang memprioritaskan keaktifan mahasiswa dengan membentuk kelompok. Kedua model juga membuat diskusi santai dan tidak kaku karena mahasiswa memiliki peran di sini. Kedua model juga melibatkan media pembelajaran yaitu media visual berupa gambar. 
Pembelajaran kooperatif merupakan model pembelajaran yang sudah umum dilakukan dalam kegiatan belajar mengajar. Ada beberapa penelitian yang penelitian relevan dengan penelitian ini, yaitu penelitian Ruswana (2019), Karsono \& Widodo (2011), dan Triani (2016). Penelitian Ruswana menerapkan model pembelajaran kooperatif tipe Formulate-Share-Listen-Create untuk meningkatkan kemampuan pemahaman matematis mahasiswa, sedangkan penelitian Karsono \& Widodo menerapkan pembelajaran kooperatif tipe jigsaw untuk meningkatkan pemahaman materi perkuliahan teknik permesinan. Selanjutnya, penelitian Triani menerpakan hal yang sama yaitu penerapan pemebelajaran kooperatif tipe jigsaw di perguruan tinggi. Ketiga penelitian ini menunjukkan bahwa model pembelajaran kooperatif dapat meningkatkan kemampuan kognitif dan mahasiswa dalam memahami dan mengonstruksi pengetahuannya sendiri.

Ada prinsip-prinsip yang harus muncul di dalam model pembelajaran kooperatif, yaitu 1) positive interdependence; 2) promotive interaction; 3) effort to achieve; 4) positive relationship; 5) psychological adjustment, social competence (Huda, 2013 \& Laal, 2013). Kelima prinsip tersebut bermuara pada satu tujuan bagaimana kerja sama kelompok menghasilkan kegiatan positif yaitu saling berbagi informasi dan pengetahuan. Sesuai dengan yang disampaikan Laal (2013).

\section{What I hear, I forget \\ What I hear and see, I remember a little \\ What I hear, see, and ask questions about or discuss with someone else, I begin to understand \\ What I hear see, discuss and do, I acquire knowledge and skills \\ What I teach to another, I master.}

Artinya bahwa dalam model ini, mahasiswa mengajari satu sama lain tanpa maksud menggurui. Penggunaan teknik Personal Selling Presentation pada model ini memiliki tujuan tersebut. Teknik inilah yang membedakan penelitian ini dengan ketiga penelitian yang disebutkan di atas. Teknik Personal Selling Presentation diadopsi peneliti dari kegiatan seorang "Salesman". Personal Selling disebut juga penjualan tatap muka atau penjualan pribadi. Menurut Wardhana \& Iba (2014), dengan teknik ini penjual dapat mengetahui reaksi langsung dari calon pembeli sehingga terjadi komunikasi dua arah antar pembeli dan penjual. Pernyataan inilah yang sesuai dengan prinsip dari pembelajaran kooperatif, bahwa ada interaksi antara peserta didik yang berperan sebagai pembeli dan penjual. Penjual sebagai kelompok penyaji dan pembeli sebagai peserta.

Model pembelajaran kooperatif ini dilaksanakan dengan bantuan teknik personal selling presentation. Model pembelajaran ini mengutamakan kerja sama antar anggota dengan berperan sebagai pembeli dan penjual dengan bantuan brosur dan pamflet sebagai media pembelajaran. Sebaliknya, model pembelajaran world café yang juga diterapkan pada penelitian ini adalah model yang memfokuskan bagaimana menciptakan sebuah tempat belajar yang nyaman yang dilambangkan dengan kafe. World café menggunakan kelompok dengan peran pramusaji kafe dan pelanggan/pembeli. Media pembelajaran model ini berupa daftar menu.

World Cafe memang terbilang cukup baru dalam dunia pendidikan Indonesia World café biasanya dilaksanakan dalam kegiatan pelatihan dan bimtek (bimbingan teknis). Penelitian tentang world café dilakukan oleh Farr (2013), Fallon \& Connaughton (2016), Eriaan \& Cady (2012), dan Antwerpen (2020). Penelitian Faar, Fallon \& Connaughton, dan Antwerpen dilatarbelakangi untuk mengubah sebuah evaluasi pembelajaran yang terfokus pada guru dan penilaian tertulis menjadi penilaian berdasakan ide dan inovasi mahasiswa, kolaborasi antar mahasiswa, keaktifan mahasiswa, dan curah pendapat mereka. Berbeda dengan ketiga penelitian sebelumnya, penelitian Eriaan \& Cady untuk meningkatkan performa pegawaianya dengan cara role playng menggunakan model world café. Ilustrasi World Café adalah kafe yang berisi daftar menu, pelayan, dan pelanggan. Pelaksanaannya adalah "circulating focus group" (Farr, 2013). Jika dalam pembelajaran kooperatif (Personal Selling Presentation), tim/kelompok melakukan presentasi secara bergantian maka world café dilakukan secara serentak dengan pembeli atau pelanggan yang beredar dari satu kafe ke kafe lain. 
Pada model world café, mahasiswa melakukan brainstorming. Ide-ide atau materi disajikan dengan kata kunci atau simbol yang mewakili (gambar) oleh kelompok penjual. Dengan brainstorming, ide-ide dari pembeli yang disampaikan secara spontan ini bisa diterima tanpa perlu menilai benar / salah. Berbeda dengan penelitian sebelumnya, penggunaan model world café diterapkan untuk melihat kemampuan kognitif mahasiswa terutama ranah kognitif "memahami". Oleh karena itu, tujuan dari penelitian ini adalah 1) mendeskripsikan kemampuan kognitif "memahami" mahasiswa menggunakan model pembelajaran kooperatif dengan teknik personal selling presentation dan model pembelajaran world café dan 2) mendeskripsikan perbedaan penggunaan dua model tersebut dengan model pembelajaran konvensional pada pembelajaran Telaah Kurikulum dan Buku Teks.

\section{METODOLOGI}

Penelitian ini adalah penelitian eksperimen dengan desain Posttest Only Control Group. Ada dua kelompok eksperimen dan satu kelompok kontrol. Kedua kelompok diberi perlakuan berbeda, sedangkan kelompok ketiga adalah kelompok yang tidak diberi perlakuan. Grup kontrol ini menjadi perbandingan untuk melihat perubahan yang terjadi karena variabel independen dalam grup eksperimen.

Tabel 1. Desain Eksperimen

\begin{tabular}{cccccc}
\hline No. & Kelompok & Pretest & \multicolumn{2}{c}{ Perlakuan } & Postest \\
\hline 1 & $\begin{array}{c}\text { Eksperimen 1 } \\
(\text { E-1) }\end{array}$ & - & X1 & $\begin{array}{c}\text { Pembelajaran kooperatif dengan teknik } \\
\text { Personal Selling Presentation }\end{array}$ & O2 \\
\hline 2 & $\begin{array}{c}\text { Eksperimen 2 } \\
(\text { E-2) }\end{array}$ & - & X2 & World Café & O2 \\
\hline 3 & Kontrol $(\mathrm{K})$ & - & - & - & O3 \\
\hline
\end{tabular}

Sintaks model pembelajaran Kooperatif dengan teknik Personal Selling Presentation tersaji pada Tabel 2.

Tabel 2. Sintaks Pembelajaran Kooperatif

\begin{tabular}{|c|c|c|}
\hline No. & Tahapan & Penjelasan \\
\hline 1 & $\begin{array}{c}\text { Menentukan anggota } \\
\text { kelompok }\end{array}$ & $\begin{array}{l}\text { Dosen memilih setiap anggota kelompok. Anggota kelompok dipilih secara } \\
\text { heterogen, misalnya kemampuan, karakter, dan jenis kelamin. Ada } \\
\text { kecenderungan mahasiswa perempuan ketika membentuk kelompok lebih } \\
\text { memilih satu sama lain dan sulit untuk bergabung dengan mahasiswa laki- } \\
\text { laki. }\end{array}$ \\
\hline 2 & $\begin{array}{l}\text { Menentukan ketua } \\
\text { kelompok }\end{array}$ & Dosen memilih ketua setiap kelompok secara acak. \\
\hline 3 & $\begin{array}{l}\text { Implementasi } \\
\text { Pembelajaran }\end{array}$ & $\begin{array}{l}\text { a. Tentukan tema (setiap tim memiliki tema yang berbeda dengan materi } \\
\text { yang berbeda). Tema tersebut dianggap sebagai produk yang akan dijual. } \\
\text { b. Siapkan materi dalam bentuk pamflet atau brosur. Sebuah } \\
\text { brosur/pamflet menjadi bagian yang tidak terpisahkan pada kegiatan } \\
\text { pemasaran sebuah produk. Saat mengenalkan produk, brosur/pamflet } \\
\text { menjadi daya tarik tersendiri karena gambar dan tulisannya. } \\
\text { c. Kelompok mempromosikan produknya secara bergantian. } \\
\text { d. Kelompok yang mempromosikan produknya disebut dengan penjual } \\
\text { dan kelompok yang mendengarkan promosi tersebut dianggap sebagai } \\
\text { pembeli. }\end{array}$ \\
\hline 4 & Penilaian & $\begin{array}{l}\text { Kelompok (penjual) dinilai oleh pembeli (peer-assesment) dan dosen. } \\
\text { Penilaian dilihat dari banyaknya peserta yang tertarik dengan apa yang } \\
\text { disuguhkan, dengan cara memberikan reward "bintang" bagi presenter. } \\
\text { Penilaian juga dilihat dari seberapa besar minat pembeli, semakin banyak }\end{array}$ \\
\hline
\end{tabular}


pembeli yang bertanya berarti produk yang dijual semakin menarik.

Sementara sintaks model pembelajaran World Café disajikan pada Tabel 3.

Tabel 3. Sintaks Pembelajaran World Café

\begin{tabular}{|c|c|c|}
\hline No. & Tahapan & Penjelasan \\
\hline 1 & $\begin{array}{c}\text { Menentukan anggota } \\
\text { kelompok }\end{array}$ & $\begin{array}{l}\text { Dosen memilih setiap anggota kelompok. Anggota kelompok dipilih secara } \\
\text { heterogen, misalnya kemampuan, karakter, dan jenis kelamin. Ada } \\
\text { kecenderungan mahasiswa perempuan ketika membentuk kelompok lebih } \\
\text { memilih satu sama lain dan sulit untuk bergabung dengan mahasiswa laki- } \\
\text { laki. }\end{array}$ \\
\hline 2 & $\begin{array}{l}\text { Menentukan pramusaji } \\
\text { dan pembeli }\end{array}$ & $\begin{array}{l}\text { a. Dosen memilih pramusaji dan pembeli di setiap kelompok secara acak. } \\
\text { b. Pramusaji bertugas untuk menjelaskan daftar menu (materi } \\
\text { pembelajaran) kepada pembeli yang datang ke kafé. } \\
\text { c. Pembeli bertugas menikmati cita rasa (menu yang ditawarkan) setiap } \\
\text { kafe. }\end{array}$ \\
\hline 3 & $\begin{array}{l}\text { Implementasi } \\
\text { Pembelajaran }\end{array}$ & $\begin{array}{l}\text { a. Tentukan nama kafe. } \\
\text { b. Tentukan topik tiap kelompok.. } \\
\text { c. Tuliskan topik (dalam bentuk kata kunci) atau bentuk gambar di daftar } \\
\text { menu. } \\
\text { d. Menu biasanya dibuat dalam bentuk flip chart, bisa diganti dengan } \\
\text { penggunaan karton. } \\
\text { e. Pramusaji menjelaskan daftar menu yang dijual, pembeli mendengarkan } \\
\text { penjelasan tersebut dan memberikan saran atau masukkan untuk menu } \\
\text { yang disajikan. } \\
\text { f. Pramusaji tidak berpindah tempat dan hanya berada di kafe masing- } \\
\text { masing, sedangkan pembeli bergerak dari kafe satu ke kafe lain. } \\
\text { g. Setelah pembeli kembali ke kelompoknya masing-masing, pembeli yang } \\
\text { merupakan anggota kelompok menyimpulkan apa yang mereka dapatkan } \\
\text { dari kafe-kafe lain di kelompoknya masing-masing. }\end{array}$ \\
\hline 4 & Penilaian & $\begin{array}{l}\text { a. Pramusaji dinilai oleh dosen. } \\
\text { b. Pembeli dinilai oleh pramusaji (peer-assesment) } \\
\text { c. Penyajian kelompok dinilai oleh pembeli yang datang ke setiap kafe. }\end{array}$ \\
\hline
\end{tabular}

Populasi penelitian ini adalah semua mahasiswa Program Studi Pendidikan Bahasa dan Sastra Indonesia yang mengikuti mata kuliah Telaah Kurikulum dan Buku Teks. Jumlah mahasiswa yang mengikuti mata kuliah tersebut adalah 67 orang, yang dibagi menjadi 3 kelas yaitu I-01, I-02, dan I-03. Kelas I-01 sebagai kelas eksperimen 1, kelas I-02 sebagai kelas eksperimen 2, dan kelas kontrol adalah I-03. Saat proses penelitian, mahasiswa yang hadir sebanyak 65 orang. Teknik pengambilan sampel disebut sampling jenuh artinya seluruh mahasiswa menjadi sampel dalam penelitian ini dan pemilihan kelas eksperimen dan kontrol secara acak karena kemampuan mahasiswa yang rata.

Data diambil menggunakan tes. Tes yang diberikan adalah tes esai. Ada 10 pertanyaan. Pertanyaan yang digunakan untuk mengukur pemahaman mahasiswa. Setelah itu, dilakukan uji prasyarat analisis data. Hasil prasyarat uji dilanjutkan menggunakan Analisis Varian (anova satu arah). Analisis menggunakan SPSS V. 22.

\section{TEMUAN}

Setelah tes dilakukan, hasil yang diperoleh dengan nilai rata-rata kelompok seperti disajikan pada Tabel 4. 
Tabel 4. Nilai Rata-Rata Kelompok

\begin{tabular}{cccc}
\hline No. & Kelompok & Jumlah Mahasiswa & Nilai Rata-Rata \\
\hline 1 & E-1 & 20 orang & 71.55 \\
\hline 2 & E-2 & 22 orang & 69.07 \\
\hline 3 & K & 23 orang & 59.34 \\
\hline
\end{tabular}

Jika dilihat dari nilai rata-rata kelompok, ada perbedaan antara kelompok eksperimen dengan kelompok kontrol. Perbedaan antara nilai rata-rata E-1 dan K adalah 12,21. Perbedaan nilai rata-rata E-2 dan $K$ adalah 9,73. Perbedaan antara kelompok E-1 dan E-2 adalah 2,48. Hasil kelompok yang diberi perlakuan memiliki nilai rata-rata lebih baik daripada kelompok kontrol. Namun, agar lebih akurat dan untuk melihat perbedaan yang signifikan antara kelompok eksperimen dan kontrol, maka dilakukan pengujian hipotesis. Pengujian hipotesis menggunakan uji ANOVA satu arah. Sebelum itu, dilakukan prasyarat tes, yaitu, uji homogenitas dan normalitasnya.

Berdasarkan uji normalitas menggunakan uji Kolmogrov-Sminorv (sampel $>50$ ), data berdistibusi normal. Hal ini disebabkan karena nilai "sig." 0,2> 0,05 sebagaimana disajikan pada Tabel 5.

Tabel 5. Uji Normalitas

\begin{tabular}{ccc}
\hline No. & Kelompok & Sig. \\
\hline 1 & E-1 & 0.200 \\
\hline 2 & E-2 & 0.200 \\
\hline 3 & K & 0.200 \\
\hline
\end{tabular}

Sementara hasil uji normalitas, ketiga kelompok memiliki nilai varian yang sama (homogenitas) karena nilai "sig." 0,883>0,05 (Tabel 6).

Tabel 6. Uji Homogenitas

\begin{tabular}{cc}
\hline Kelompok & Sig. \\
\hline E-1, E-2, K & 0.883 \\
\hline
\end{tabular}

Berdasarkan hasil uji normalitas dan homogenitas, data terdistribusi normal dan memiliki nilai varian yang sama (homogen). Oleh karena itu, analisis menggunakan uji ANOVA satu arah.Hasil dari uji ANOVA sebagai berikut.

Tabel 7. Uji ANOVA

\begin{tabular}{cc}
\hline Kelompok & Sig. \\
\hline Antarkelompok & 0.001 \\
\hline
\end{tabular}

Nilai sig. yang diperoleh menggunkan uji ANOVA adalah 0,001. Itu artinya 0,001 kurang dari 0,05. Ini berarti bahwa ada perbedaan antara nilai rata-rata mahasiswa yang belajar menggunakan pembelajaran kooperatif, world café, dan pembelajaran secara konvensional. Untuk melihat perbedaannya lebih jauh lagi, menggunakan post hoc.

Tabel 8. Perbandingan Antarkelompok

\begin{tabular}{ccc}
\hline (I) & (J) & Sig. \\
\hline E-1_E-2_K & E-1_E-2_K & 0.749 \\
\hline E-1 & E-2 & 0.002 \\
\hline E-2 & E-1 & 0.749 \\
& K & 0.013 \\
\hline K & E-1 & 0.002 \\
& E-2 & 0.013 \\
\hline
\end{tabular}


Jika nilainya sig. $<0,05$, ada perbedaan yang signifikan antar kelompok. Berdasarkan tabel HSD Turki Post Hoc (Tabel 9), perhatikan perbedaan kelompok yang dirangkum pada Tabel 9.

Tabel 9. Perbedaan Signifikan

\begin{tabular}{cc}
\hline Antar Kelompok & Ukuran Perbedaan \\
\hline E-1 dan E-2 & Tidak Signifikan \\
\hline E-1 dan K & Signifikan \\
\hline E-2 dan K & Signifikan \\
\hline
\end{tabular}

Dari tabel 9, diketahui bahwa nilai rata-rata antara kelompok eksperimen 1 dan 2 tidak memiliki perbedaan yang signifikan. Namun, rata-rata nilai antara kelompok eksperimen 1 dan 2 memiliki perbedaan yang signifikan dengan kelompok kontrol. Hasil penelitian ini menunjukkan bahwa model pembelajaran kooperatif dengan teknik personal selling presentation dan world café memberikan pengaruh yang baik terhadap kemampuan kognitif mahasiswa.

\section{DISKUSI}

Tujuan dari penelitian ini adalah mendeskripsikan kemampuan kognitif "memahami" mahasiswa menggunakan model pembelajaran kooperatif dengan teknik personal selling presentation dan model pembelajaran world café dan mendeskripsikan perbedaan penggunaan dua model tersebut dengan model pembelajaran konvensional pada pembelajaran Telaah Kurikulum dan Buku Teks. Hasilnya bahwa antara dua model yang telah dicoba (pembelajaran kooperatif dengan teknik personal selling presentation dan world cafe) tidak memiliki perbedaan yang signifikan, tetapi kedua model ini memiliki perbedaan dengan model pembelajaran konvensional. Kedua model ini memiliki peringkat rata-rata yang lebih baik daripada model pembelajaran konvensional yang digunakan di kelas kontrol. Itu berarti bahwa kedua model dapat diterapkan dalam Telaah Kurikulum dan Buku Teks dan dapat membantu mengembangkan kemampuan kognitif mahasiswa.

Belajar menggunakan pembelajaran kooperatif dengan teknik personal selling presentation dan world café memiliki kesamaan, yaitu pemilihan anggota kelompok, pemanfaatan gambar, dan penilaian sejawat. Pertama, tentang pemilihan anggota kelompok. Pembelajaran kooperatif dan world café memiliki anggota kelompok yang heterogen, sedangkan pada kelompok kontrol mahasiswa memilih anggota kelompok mereka sendiri. Kelompok-kelompok yang ada di kelas eksperimen dipilih berdasarkan kemampuan, jenis kelamin, dan karakter (Ngalimun, 2014). Dosen dalam hal ini, sudah harus mengetahui ciri-ciri tersebut sebelumnya (ini dilakukan pada pertemuan pertama). Pemilihan kelompok heterogen akan membuat hasil belajar yang lebih baik (Bernacki \& Kozierkiewicz-Hetmańska, 2015; Kagan, 2015). Keberadaan kelompok heterogen membuat banyak pemikiran berbeda (brainstroming) dan tidak ada dominasi yang terlalu mencolok dalam suatu kelompok.

Selain itu, pemilihan ketua kelompok dalam pembelajaran kooperatif dan pemilihan penjual di world cafe berpengaruh pada hasil dan proses pembelajaran. Ada kecenderungan jika mahasiswa menentukan sendiri ketua kelompok, mahasiswa yang dipilih adalah mahasiswa yang sudah terbiasa berbicara di depan kelas, yang biasanya aktif di kelas. Hasilnya, mahasiswa lain (anggota kelompok) akan bersikap pasif karena mengandalkan ketua. Oleh karena itu, pemimpin kelompok atau penjual dalam kedua model pembelajaran dipilih secara acak, sehingga memberikan kesempatan kepada semua anggota di kelompok.

Kedua, pemanfaatan gambar dalam bentuk brosur atau pamflet dan daftar menu. Penggunaan gambar bukan tanpa alasan, alasannya adalah memberikan pemahaman yang lebih baik dalam belajar (Pujiastuti, 2017). Deskripsi ini juga cocok dengan Vella (1992) yang 
menyampaikan bahwa warna pada gambar dapat membuat kegiatan belajar menjadi lebih menarik dan menyenangkan. Ini juga ditekankan dalam penelitian Dzulkifli \& Mustafar (2013) bahwa warna-warna yang terdapat dalam sebuah gambar, ilustrasi, atau pamflet dan brosur memengaruhi kemampuan otak dalam merekam ingatan atau dengan kata lain memudahkan seseorang untuk mengingat. Selain itu, gambar juga membuat mahasiswa meningkatkan kemampuannya memahami dan menjelaskan kembali ingatan yang sudah disimpannya.

Penilaian ketiga oleh mahasiswa penilaian ini disebut penilaian sejawat. Ketika seorang mahasiswa dievaluasi oleh dosen, maka mereka teralu banyak berpikir (overthinking) kemudian gugup dan takut salah. Berbeda ketika mereka dinilai oleh teman sebaya, mereka bebas melakukan eksplorasi atas apa yang mereka pikirkan. Hasil penilaian ketika proses pembelajaran di kelas eksperimen berbeda dengan kelas kontrol. Hal ini sejalan dengan penelitian Wijayanti bahwa penilaian sejawat akan memberikan pengaruh positif pada afektif (perilaku) peserta didik. Akibatnya pengembangan pengetahuan (kognitif) dan keterampilan (psikomotor) juga meningkat (Wijayanti, 2017). Penelitian lain juga memberikan penilaian positif bahwa penilaian sejawat berpengaruh pada kegiatan belajar mengajar (Rochmiyati, 2012) \& (Karami \& Rezaei, 2015).

Pada dasarnya model pembelajaran kooperatif dan world café melibatkan tiga gaya belajar siswa yaitu Visual, Audio, dan Kinestetik (VAK). Belajar tidak difokuskan pada mahasiswa yang selalu aktif, mahasiswa yang pasif akan mulai bergerak aktif. Mahasiswa belajar menggunakan gaya visual, mereka dapat mengerti melalui gambar. Mahasiswa yangmenggunakan gaya belajar kinestetik, mereka bisa menjadi penyaji atau pindah dari satu kelompok ke kelompok lain dan bisa bertindak apa yang mereka inginkan. Mahasiswa yang belajar menggunakan gaya audio, mereka bisa mendengarkan presentasi atau penjualan temannya. Mahasiswa pada akhirnya dapat belajar dengan gaya belajar mereka masing-masing.

Dengan demikan, kedua model pembelajaran tersebut dapat merangsang kemampuan berpikir mahasiswa sehingga meningkatkan pemahaman kognitif mereka. Hal ini juga sejalan dengan penelitian Othman \& Amiruddin (2010) bahwa model pembelajaran yang melibatkan gaya belajar mahasiswa tidak hanya mengandalkan ingatan mahasiswa. Namun, hal ini berkaitan dengan kemampuan memperoleh atau memahami informasi atau pengetahuan baru. Tidak hanya itu lingkungan belajar yang menyenangkan dan interaksi membuat suasana belajar menjadi lebih baik seperti diungkapkan Reiff (1992, dalam Wicaksono, 2016) dan Othman \& Amiruddin (2010). Ketika mahasiswa memiliki keinginan belajar maka dengan sendirinya berpengaruh pada kemampuan kognitif. Piaget dan Freire menjelaskan bahwa mahasiswa berhasil atau tidak menggali ilmunya tergantung pada bagaimana pendidikan dapat menciptakan kondisi dan situasi yang memungkinkan mahasiswa untuk membentuk makna materi pelajaran melalui proses pembelajaran dan menyimpannya dalam memori kapan saja dapat diproses dan dikembangkan lebih lanjut (Nuraeni, Rahman, \& Arief, 2008).

Adapun keterbatasan penelitian ini adalah waktu yang dibutuhkan cukup lama apalagi jika mahasiswa tidak memahami secara jelas tentang sintaks pembelajaran. Jadi guru/dosen yang ingin menerapkan kedua model ini perlu memahami lebih dalam tentang sintaks kedua model pembelajaran.

\section{SIMPULAN}

Kedua model pembelajaran dapat digunakan dalam proses pembelajaran terutama untuk materimateri yang bersifat teoretis. Model-model ini memberikan pengaruh dalam proses peningkatan kemampuan kognitif. Ini disebabkan oleh tiga poin utama yang diterapkan dalam model yaitu, kerja tim, visual, dan penilaian sejawat.

Tiga poin utama ini menciptakan lingkungan belajar yang baik. Lingkungan belajar yang baik membantu mahasiswa menggali kemampuan. Selain itu penerapan pembelajaran 
memanfaatkan gaya belajar siswa. Gaya belajar, visual, audio, dan kinestetik tercermin dalam setiap kegiatan. Mahasiswa mendengarkan, membaca, berbicara, dan juga bergerak untuk mengeksplorasi. Gaya belajar siswa akan membantu mengoptimalkan hasil penelitian, hingga akhirnya berpengaruh pada peningkatan pemahaman mahasiswa.

Saran untuk guru, dosen, atau yang ingin menerapkan kedua model pembelajaran ini adalah memahami sintaks pembelajaran sehingga dapat memanfaatkan waktu pembelajaran secara optimal. Selain itu, pendidik dapat memadukan kedua model pembelajaran dengan mind map. Teknik personal selling presentation, pembelajaran dapat dipadukan dengan model pembelajaran luring atau bybrid learning. Selanjutnya, diharapkan penelitian ini dapat dijadikan referensi untuk penelitian serupa atau penelitian-penelitian tentang kemampuan kognitif lainnya

\section{REFERENSI}

Anderson, L. W., \& Krathwohl, D. R. (2010). Kerangka Landasan untuk Pembelajaran, Pengajaran, dan Asesmen. Yogyakarta: Pustaka Pelajar.

Antwerpen, U. (2020). World Café as a Participatory Approach to Facilitate the Implementation Process of Problem-Based Learning. Journal of Problem Based Learning in Higher Education, 8(1). https://doi.org/10.5278/ojs.jpblhe.v8i1.2660

Bernacki J., \& Kozierkiewicz-Hetmańska, A. (2015) The Comparison of Creating Homogeneous and Heterogeneous Collaborative Learning Groups in Intelligent Tutoring Systems. In: Nguyen N., Trawiński B., Kosala R. (eds) Intelligent Information and Database Systems. ACIIDS 2015. Lecture Notes in Computer Science, vol 9011. Springer, Cham. https://doi.org/10.1007/978-3-319-15702-3_5

Dzulkifli, M. A., \& Mustafar, M. F. (2013). The influence of colour on memory performance: a review. The Malaysian Journal of Medical Sciences : MJMS, 20(2), 3-9. Retrieved from http://www.ncbi.nlm.nih.gov/pubmed/23983571\%0Ahttp://www.pubmedcentral.nih.gov /articlerender.fcgi?artid $=$ PMC3743993

Eriaan, O., \& Cady, S. H. (2012). The world café in South Africa: A case study on improving performance and commitment. Organization Development Journal, 30(1), 79-90.

Fallon, H., \& Connaughton, L. (2016). Using a World Café to Explore New Spaces and New Models for Front Line Services: A Case Study from the Irish University Library Sector. New Review of Academic Librarianship, 22(1), 43-59. https://doi.org/10.1080/13614533.2015.1126291

Farr, J. (2013). "Shared listening": using a World cafe approach as a revision tool in a final year undergraduate programme. Compass: Journal of Learning and Teaching, 4(8). https://doi.org/10.21100/compass.v4i8.78

Hadi, S. (2016). Peningkatan Pemahaman Mahasiswa Pada Mata Kuliah Telaah Kurikulum Melalui Media Visual Berbasis Macromedia Flash Mx. Dinamika Pendidikan, 6(2), 132-149. https://doi.org/10.15294/dp.v6i2.5108

Huda, M. (2013). Model-Model Pengajaran dan Pembelajaran: Isu-isu Metodis dan Paradigmatis. Yogyakarta: Pustaka Pelajar.

Jacobsen, D. A., Eggen, P., \& Kauchak, D. (2009). Methods for Teaching: Metode-Metode Pengajaran Meningkatkan Belajar Siswa TK-SMA (1 st ed.). Yogyakarta: Pustaka Pelajar.

Kagan, S. (2015). 10 Reasons to Use Heterogeneous Teams. Kagan Online Magazine. Retrieved from https://www.kaganonline.com/free_articles/dr_spencer_kagan/396/10-Reasons-toUse-Heterogeneous-Teams

Karami, A., \& Rezaei, A. (2015). An Overview of Peer-Assessment: The Benefits and Importance. Journal for the Study of English Linguistics, 3(1), 93. https://doi.org/10.5296/jsel.v3i1.7889 
Karsono, \& Widodo, R. D. (2011). Keefektifan Model Pembelajaran Kooperatif Tipe Jigsaw terhadap Peningkatan Pemahaman Materi Mata Kuliah Praktik Permesinan. Pendidikan Teknik $\quad$ Mesin, 11, 63-67. from https://journal.unnes.ac.id/nju/index.php/JPTM/article/view/1974

Laal, M. (2013). Collaborative Learning; Elements. Procedia - Social and Behavioral Sciences, 83, 814 818. https://doi.org/10.1016/j.sbspro.2013.06.153

Muhson, A. (2009). Upaya Peningkatan Minat Belajar Dan Pemahaman Mahasiswa Melalui Penerapan Problem-Based Learning. Jurnal Kependidikan: Penelitian Inovasi Pembelajaran, 39(2), 197340. https://doi.org/10.21831/jk.v39i2.203

Ngalimun. (2014). Strategi dan Model Pembelajaran (III). Yogyakarta: Aswaja Pressindo.

Nuraeni, E., Rahman, T., \& Arief, M. H. (2008). the Effectiveness of Audio-Visual Teaching Media in Supporting Student Learning of Human Growth. International Conference on Lesson Study (ICLS 2008), (February). Retrieved from http:// file.upi.edu/Direktori/FPMIPA/JUR._PEND._BIOLOGI/197606052001122-

ENI_NURAENI/MAKALAH/makalah_lengkap_AV_LS.pdf

Othman, N., \& Amiruddin, M. H. (2010). Different perspectives of learning styles from VARK model. Procedia - Social and Behavioral Sciences, 7(December), 652-660. https://doi.org/10.1016/j.sbspro.2010.10.088

Pujiastuti, I. (2017). Pengaruh Metode Diskusi Berbantuan Mind Mapping. Bahastra, 37, 148-155.

Rochmiyati. (2012). Model Peer Assessment pada Pembelajaran Kolaboratif Elaborasi IPS Terpadu di Sekolah Menengah Pertama. Jurnal Penelitian Dan Evaluasi Pendidikan, 16(1), 246267. https://doi.org/https://doi.org/10.21831/pep.v16i1.1120

Ruswana, A. M. (2019). Meningkatkan Kemampuan Pemahaman Matematis Mahasiswa melalui Pembelajaran Kooperatif Tipe Formulate-Share-Listen-Create ( FSLC ). Prisma Sains, 7(1), 91-99.

Retrieved

from http://ojs.ikipmataram.ac.id/index.php/prismasains/article/view/1424

Triani, D. A. (2016). Implementasi Strategi Pembelajaran Kooperatif ( Cooperative Learning ) Tipe Jigsaw Di Perguruan Tinggi. Universum: Jurnal Keislaman Dan Kebudayaan, 10, 219-227. Retrieved from https://jurnal.iainkediri.ac.id/index.php/universum/article/view/262

Vella, F. (1992). Learning to Think: Thinking to Learn. Biochemical Education, 20(2), 120. https://doi.org/10.1016/0307-4412(92)90128-9

Wardhana, A., \& Iba, Z. (2014). Pengaruh Penjualan Personal Terhadap Pengetahuan Produk Dan Implikasinya Terhadap Keputusan Pembelian Mobil Suv Premium Di Jawa Barat. Jurnal Kebangsaan, 3(5), 1-10.

Wicaksono, A. G. C. (2016). Perbandingan Kemampuan Kognitif dan Metakognitif Mahasiswa dengan Gaya Belajar yang Berbeda. Jurnal Media Penelitian Pendidikan, 10(2), 142-153. https://doi.org/10.26877/mpp.v10i2.1516

Wijayanti, A. (2017). Efektivitas Self Assessment dan Peer Assessment dalam Pembentukan Karakter Siswa. Realita, 15(2), 1-14. Retrieved from https://jurnal.iainkediri.ac.id/index.php/realita/article/viewFile/482/311 